\title{
309 MR assessment of myocardial perfusion, viability and function after intramyocardial transfer of plasmid expressing two isoforms of hepatocyte growth factor in swine model

\author{
Maythem Saeed*, Alastair Martin, Loi Do, Matthew Bucknor, David Saloner \\ and Charles Higgins
}

Address: Univerisity of California San Francisco, San Francisco, CA, USA

* Corresponding author

from I Ith Annual SCMR Scientific Sessions

Los Angeles, CA, USA. I-3 February 2008

Published: 22 October 2008

Journal of Cardiovascular Magnetic Resonance 2008, IO(Suppl I):AII2 doi:I0.II86/I532-429X-I0-SI-AII 2

This abstract is available from: http://jcmr-online.com/content/I0/SI/AII2

(c) 2008 Saeed et al; licensee BioMed Central Ltd.

\section{Introduction}

Coronary angioplasty or bypass surgery is routinely applied to restore flow to ischemic myocardium. Nevertheless, many patients with end stage coronary artery disease continue to suffer from disabling angina. This problem has increased interest in alternative revascularization strategies (angiogenic growth factors, genes or stem cells).

\section{Purpose}

To determine the effects of intramyocardial transfer of plasmid DNA gene (HGF gene) expressing two isoforms of human hepatocyte growth factor (HGF) on perfusion, viability and LV function using MR imaging.

\section{Methods}

In this study the HGF gene was injected intramyocardially in reperfused infarction ( $2 \mathrm{hr}$ occlusion), for the purpose of evaluating this strategy as a therapeutic approach for protection from LV remodeling. MR imaging was performed at 3 days and 7-8 weeks on a 1.5-T MR clinical scanner (Philips Medical Systems). First pass perfusion, delayed contrast enhancement and cine MR imaging was used in the evaluation. Triphenyltetrazolium chloride (TTC) and histopathological (Masson's trichrome and Biotinylated Bandeiria simplicifolia isolectin $\mathrm{B}_{4}$ ) stains were utilized to quantify vascular density and myocardial viability.

\section{Results}

The peak signal intensity (SI), extents of hypoenhanced ischemic myocardium and max upslope data in the two groups were not significantly different at 3 days. At 7-8 weeks peak signal intensity was higher and maximum upslope data was steeper in treated animals compared to controls. The extent of hyperenhanced scar was significantly larger in control $(13.2 \pm 1.6 \% \mathrm{LV})$ compared with HGF treated $(7.0 \pm 0.5 \% \mathrm{LV})$ animals. TTC analysis also showed that the extent of scar tissue was significantly larger in control $(12.0 \pm 1.7 \%)$ compared with treated $(6.6 \pm 0.7 \% \mathrm{LV}, P=0.04)$ animals. There was no significant difference between the extent of hyperenhanced scar on MRI and TTC $(P=0.32)$. The infarction tended to be non-transmural with a residual thicker wall in treated compared with control animals both on MR images and TTC. Control animals showed evidence of LV remodeling, which was reflected by increased end systolic volumes and decline in ejection fraction. Treated animals showed a decrease from in end diastolic $(2.15 \pm 0.12$ to $1.82 \pm 0.12$, $P=0.008)$ and end systolic $(1.33 \pm 0.07$ to $1.00 \pm 0.08, P$ $=0.001)$ volumes. They also showed increased ejection fraction $(40.3 \pm 1.3$ to $45.7 \pm 1.8, P=0.001)$.

Quantitative analysis in control animals revealed clear gradients of capillary density between remote $(422 \pm 20$ capillaries $\left./ \mathrm{mm}^{2}\right)$, peri-infarcted myocardium $(145 \pm 7$ / $\left.\mathrm{mm}^{2}\right)$ and scar $\left(119 \pm 17 / \mathrm{mm}^{2}\right)$. In these regions, the density of blood vessels greater than $15 \mu$ was $6.4 \pm 0.3$ arteri- 


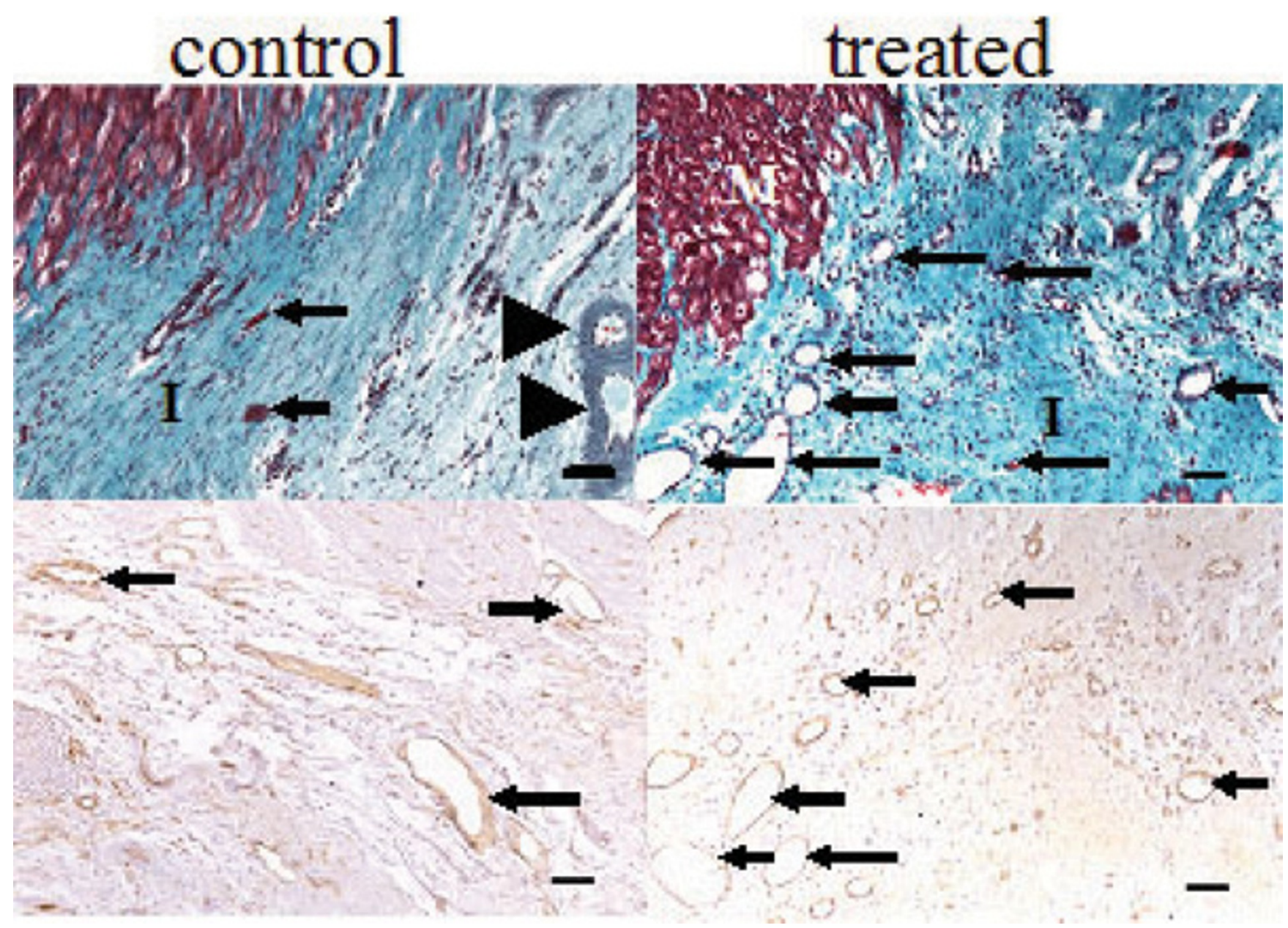

\section{Figure I}

There is a sharp boundary between the healed infarct (I) and viable myocytes (M). At 7-8 weeks following coronary artery occlusion/reperfusion. At the edge of infarction in control animals few sparse thin-walled vessels (arrows), thick-walled vessels (arrowheads) and degenerated myocytes are shown (top left). In contrast, a treated HGF heart showed an irregular healed infarct (I) borders (top right). The edge of the scar contains numerous thin-walled blood vessels (arrows). Top panels:_Masson trichrome stain. Bottom panels: biotinylated Bandeiria simplicifolia isolectin $\mathrm{B}_{4}$. Calibration bars $=45$ microns.

oles/mm², $5.2 \pm 1.6 / \mathrm{mm}^{2}$ and $2.6 \pm 0.7 / \mathrm{mm}^{2}$ respectively. Control animals showed sharp borders separating viable myocardium from scar. In contradistinction, treated animals showed irregular scars with peninsulas/ islands in peri-infarcted region and scar (Figure 1).

\section{Conclusion}

Our study is the first to demonstrate the biological effects of coexpression of HGF and dHGF in myocardial infarction. This MR study provides comprehensive assessment of myocardial perfusion, viability and function after intramyocardial transfer of therapies. It is apparent that the mechanism of improvement of global LV lies in the formation of new blood vessels and peninsulas/islands of viable cardiomyocytes.

\begin{tabular}{|} 
Publish with Bio Med Central and every \\
scientist can read your work free of charge \\
"BioMed Central will be the most significant development for \\
disseminating the results of biomedical research in our lifetime. " \\
Sir Paul Nurse, Cancer Research UK \\
Your research papers will be: \\
• available free of charge to the entire biomedical community \\
• peer reviewed and published immediately upon acceptance \\
• cited in PubMed and archived on PubMed Central \\
• yours - you keep the copyright \\
Submit your manuscript here: \\
http://www.biomedcentral.com/info/publishing_adv.asp
\end{tabular}

